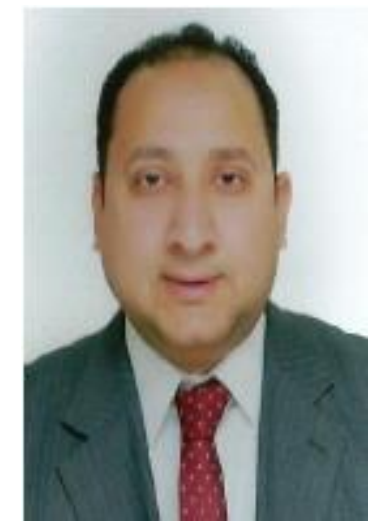

\title{
DETECTION OF SERUM LEVEL CHANGES OF MATRIX METALLOPROTIENASE-13 AND INTER LEUKIN-1 BETA DURING REMISSION AND FLARE-UPS OF PRIMARY OSTEOARTHRITIS OF THE KNEES.
}

\author{
BY \\ Yasser Abd El-Motaleb Gazar \\ Lecturer of Rheumatology, Physical medicine \& Rehabilitation \\ Faculty of Medicine \\ AI-AZHAR UNIVERSITY \\ Cairo, Egypt
}

\section{introduction:}

The diagnosis of osteoarthritis is currently based on radiographic criteria (eg, joint space width) and clinical symptoms (eg, pain and loss of function)(1).The evaluation of new disease-modifying osteoarthritis drugs (DMOADs) is performed on the same basis, since the regulatory bodies currently require evidence for an impact on radiographic joint space narrowing ( JSN) and an impact on symptoms. $(2,3)$ However, the limitations of radiography have led to research into alternative 
parameters for monitoring osteoarthritis that could serve as biomarkers in drug development.(4)

\section{Aim of the work:}

detect the serum level of MMP-13 and IL-1 $\beta$ In OA of the knee during remission and excerbation and if these Biomarkers can be validated as gold biomarkers in assessingOA progression and drug development in OA.

\section{Methods:}

This study was performed on 60 patients with knee osteoarthritis, 18 males $(30 \%)$ and 42 females(70\%), all diagnosed as osteoarthritis of one or both knees. Their ages ranged from ( $40-65)$ years. The duration of their disease ranged

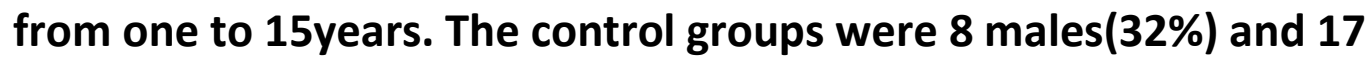
females(68\%). their ages ranged from(40-65)years

We have excluded

1.Significant conditions of the spine, hips, or feet that affect the ability to walk.

2. Significant medical conditions that affect the ability to walk and function. 3 Inflammatory arthritis, such as rheumatoid or gouty arthritis.

4 .Degenerative arthritis secondary to other conditions, such as hemochromatosis, Wilson' ${ }^{\prime} s$

disease, or ochronosis.

5. Current significant soft tissue rheumatism such as fibromyalgia, or trochanteric bursitis.

6. significant trauma and surgery (including arthroscopy) or intra-articular corticosteroid injection 
to the index knee within 6 months of enrollment.

The patients were allowed to continue on the medications that they have pro inflammatory cytokines (IL-1 $\beta$ ) and degradative enzymes (MMP-13) are measured.

Asssesing the flare-ups using Knee Osteoarthritis Flare Ups Score (KOFUS)

\section{$\underline{- \text { Results }}$}

Table (1): comparisons between demographic data in the two groups

\begin{tabular}{|c|c|c|c|}
\hline Parameters & $\begin{array}{c}\text { Patients } \\
(n=60)\end{array}$ & $\begin{array}{c}\text { Control } \\
(n=25)\end{array}$ & P-value \\
\hline $\begin{array}{l}\text { Age (Years) } \\
\quad \text { Mean } \pm \text { SD }\end{array}$ & $50.7 \pm 6.7$ & $48.2 \pm 9.1$ & 0.348 \\
\hline $\begin{array}{r}\text { Gender (n, \%) } \\
\text { Male } \\
\text { Female }\end{array}$ & $\begin{array}{l}18(30) \\
42(70)\end{array}$ & $\begin{array}{c}8(32) \\
17(68)\end{array}$ & 0.855 \\
\hline $\begin{array}{l}\text { BMI }\left(\mathrm{Kg} / \mathrm{m}^{2}\right) \\
\quad \text { Mean } \pm \text { SD }\end{array}$ & $32.4 \pm 2.9$ & $31.2 \pm 3.6$ & 0.365 \\
\hline $\begin{array}{c}\text { Disease duration (Years) } \\
\text { Mean } \pm \text { SD }\end{array}$ & $5.8 \pm 3.8$ & & \\
\hline $\begin{array}{c}\text { Affected knees (n, \%) } \\
\text { Bilateral } \\
\text { Unilateral }\end{array}$ & $\begin{array}{l}43(71.7) \\
17(28.3)\end{array}$ & & \\
\hline Mean \pm SD & $2.6 \pm 0.8$ & & \\
\hline
\end{tabular}

\section{Table (2): comparison between IL-1 $\beta$ levels in the four groups}

\begin{tabular}{|c|c|c|c|c|c|}
\hline$I L-1 \beta(P g / m l)$ & $\begin{array}{c}\text { No flare-up } \\
(n=10)\end{array}$ & $\begin{array}{c}1 \text { flare-up } \\
(n=26)\end{array}$ & $\begin{array}{c}2 \text { flare-ups } \\
(n=21)\end{array}$ & $\begin{array}{c}3 \text { flare-ups } \\
(n=3)\end{array}$ & P-value \\
\hline $\begin{array}{c}\text { Mean } \pm \text { SD } \\
\text { Median } \\
\text { Range }\end{array}$ & $\begin{array}{c}70.7 \pm 34^{b} \\
72 \\
15-126\end{array}$ & $\begin{array}{c}82.5 \pm 46.6^{b} \\
99 \\
13-148\end{array}$ & $\begin{array}{c}86.3 \pm 42.5^{b} \\
95 \\
12-144\end{array}$ & $\begin{array}{c}129 \pm 8.2^{\mathrm{a}} \\
131 \\
120-136\end{array}$ & $<0.001^{*}$ \\
\hline
\end{tabular}




\section{Table (3): comparison between MMP13 levels in the four groups}

\begin{tabular}{|c|c|c|c|c|c|}
\hline MMP13 (mg) & $\begin{array}{c}\text { No flare-up } \\
(n=10)\end{array}$ & $\begin{array}{c}1 \text { flare-up } \\
(n=26)\end{array}$ & $\begin{array}{c}2 \text { flare-ups } \\
(n=21)\end{array}$ & $\begin{array}{c}3 \text { flare-ups } \\
(n=3)\end{array}$ & P-value \\
\hline $\begin{array}{c}\text { Mean } \pm \text { SD } \\
\text { Median } \\
\text { Range }\end{array}$ & $\begin{array}{c}0.04 \pm 0.06^{\mathrm{c}} \\
0 \\
0-0.13\end{array}$ & $\begin{array}{c}0.08 \pm 0.08^{b} \\
0.10 \\
0-0.28\end{array}$ & $\begin{array}{c}0.11 \pm 0.10^{\mathrm{b}} \\
0.12 \\
0-0.28\end{array}$ & $\begin{array}{c}0.18 \pm 0.06^{\mathrm{a}} \\
0.21 \\
0.12-0.22\end{array}$ & $0.045^{*}$ \\
\hline
\end{tabular}

Table (4): comparison between KOFUS in the three groups

\begin{tabular}{c|ccc|c}
\hline KOFUS & $\begin{array}{c}\text { 1 flare-up } \\
(\boldsymbol{n}=26)\end{array}$ & $\begin{array}{c}\text { 2 flare-ups } \\
(\boldsymbol{n}=\mathbf{2 1})\end{array}$ & $\begin{array}{c}\text { 3 flare-ups } \\
(\boldsymbol{n}=\mathbf{3})\end{array}$ & P-value \\
\hline $\begin{array}{c}\text { Mean } \pm \text { SD } \\
\text { Median } \\
\text { Range }\end{array}$ & $9.9 \pm 2.1^{\mathrm{b}}$ & $10.1 \pm 1.7^{\mathrm{b}}$ & $11 \pm 1.7^{\mathrm{a}}$ & 0.615 \\
\hline
\end{tabular}

\section{Table (6): comparison between different medications in the four groups}

\begin{tabular}{|c|c|c|c|c|c|}
\hline Medications & $\begin{array}{c}\text { No flare-up } \\
(n=10)\end{array}$ & $\begin{array}{c}1 \text { flare- } u p \\
(n=26)\end{array}$ & $\begin{array}{c}2 \text { flare-ups } \\
(n=21)\end{array}$ & $\begin{array}{c}3 \text { flare-ups } \\
(n=3)\end{array}$ & P-value \\
\hline Analgesic $+\operatorname{NSAID}(n, \%)$ & $0(0)$ & $0(0)$ & $2(9.5)$ & $0(0)$ & \multirow{6}{*}{$<0.001 *$} \\
\hline Analgesic $(n, \%)$ & $0(0)$ & $0(0)$ & $0(0)$ & $1(33.3)$ & \\
\hline $\operatorname{NSAID}(n, \%)$ & $1(10)$ & $13(50)$ & $13(61.9)$ & $1(33.3)$ & \\
\hline Systemic (n, \%) & $0(0)$ & $6(23.1)$ & $2(9.5)$ & $1(33.3)$ & \\
\hline Systemic + Analgesic $(n, \%)$ & $2(20)$ & $4(15.4)$ & $2(9.5)$ & $0(0)$ & \\
\hline Systemic+ NSAID (n, \%) & $7(70)$ & $3(11.5)$ & $2(9.5)$ & $0(0)$ & \\
\hline
\end{tabular}



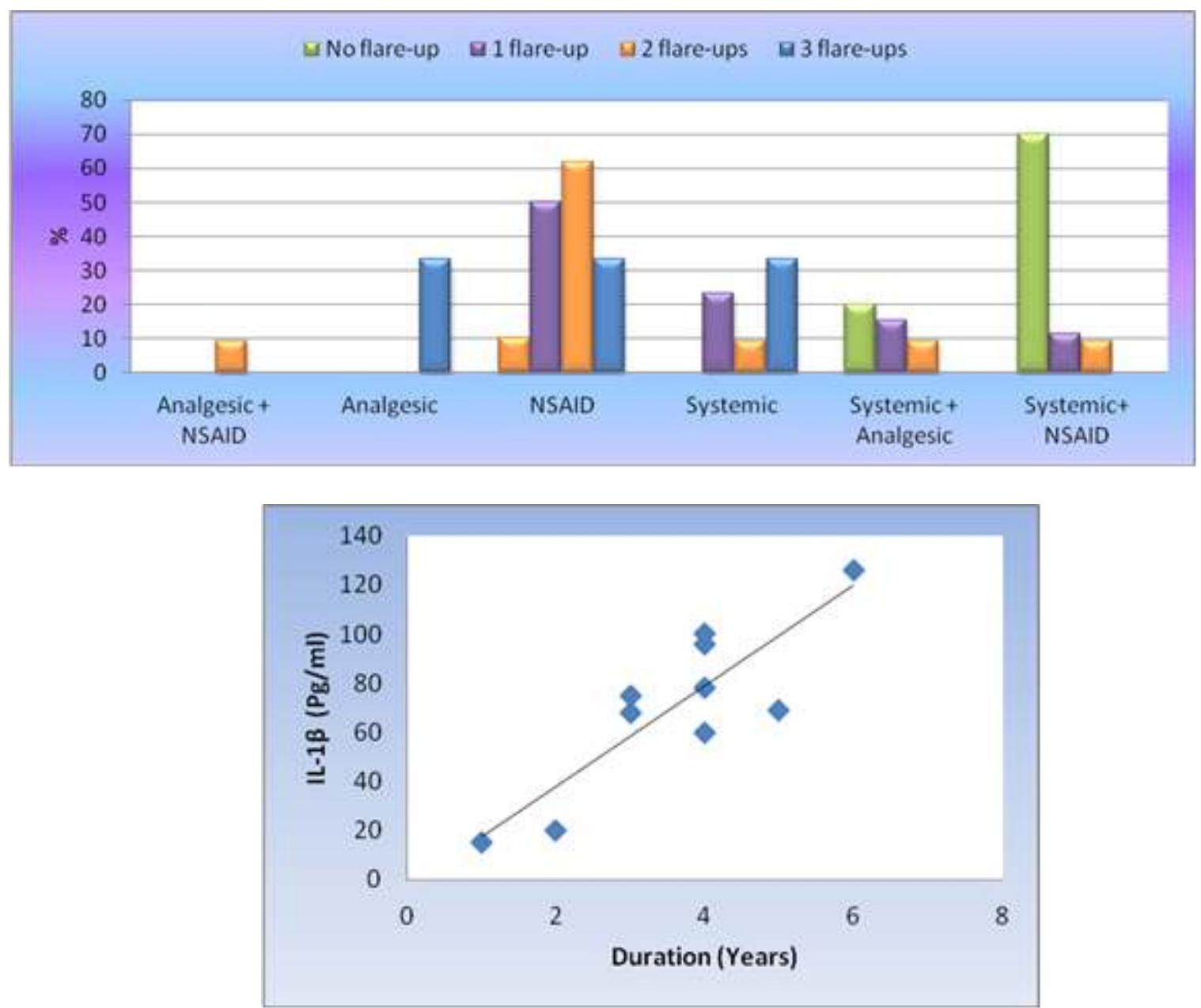

Figure (2): positive correlation between disease duration and IL-1ß level in patients with no flare-up

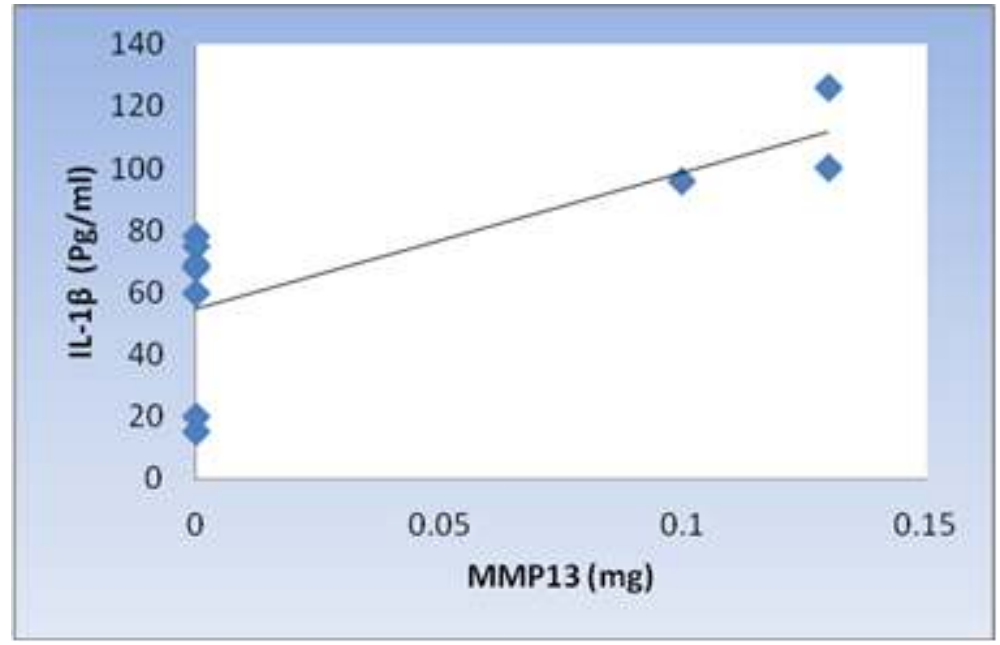


Figure (3): positive correlation between MMP13 and IL-1 $\beta$ level in patients with no flare-up

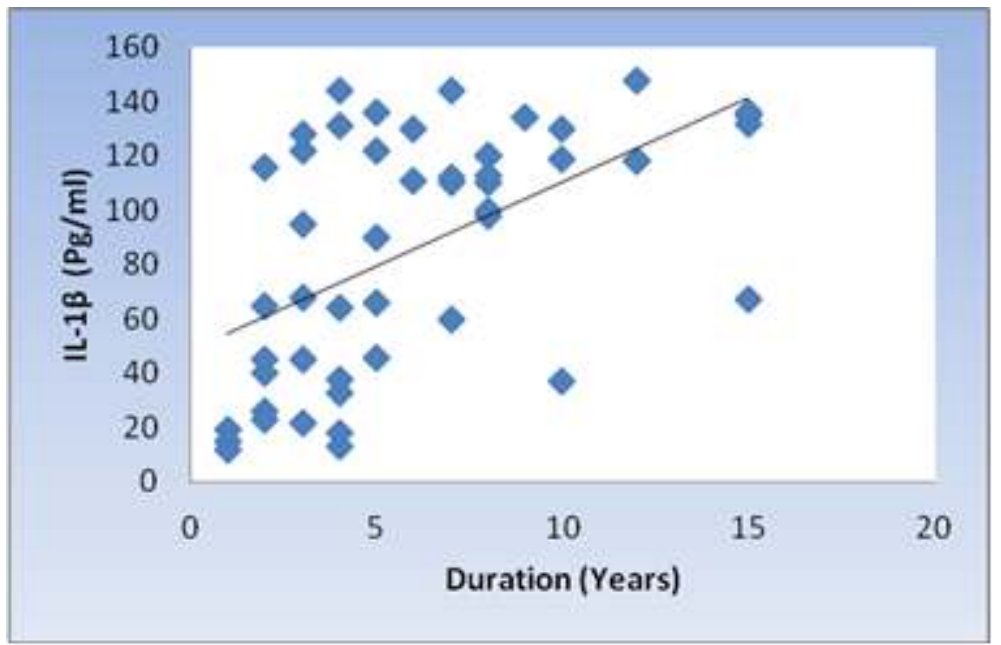

Figure (4): positive correlation between disease duration and IL-1 $\beta$ level in patients with flare-ups

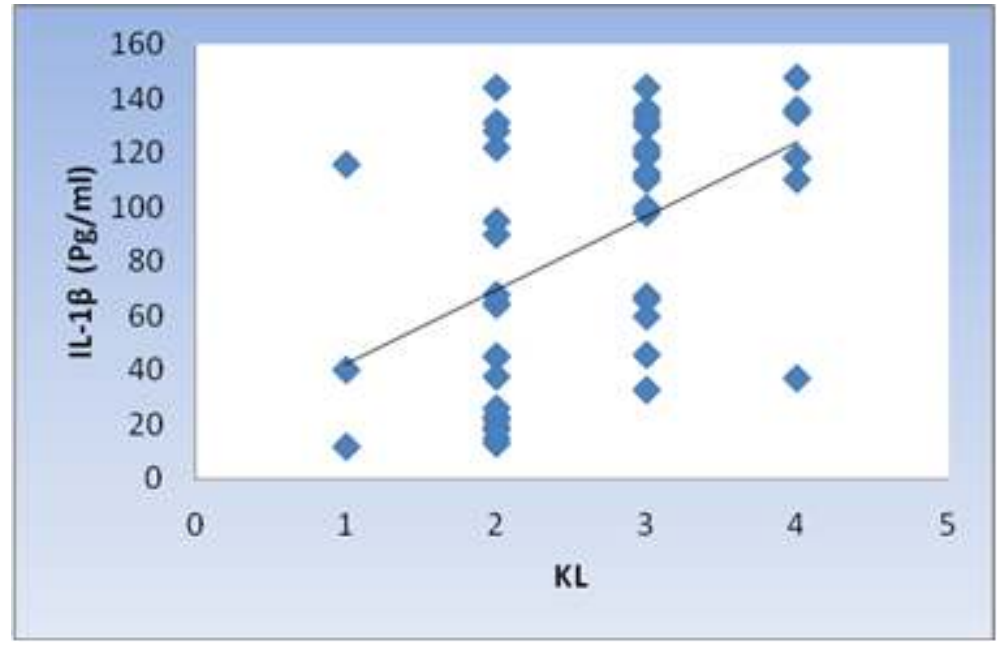

Figure (5): positive correlation between KL and IL-1 $\beta$ level in patients with flare-ups 


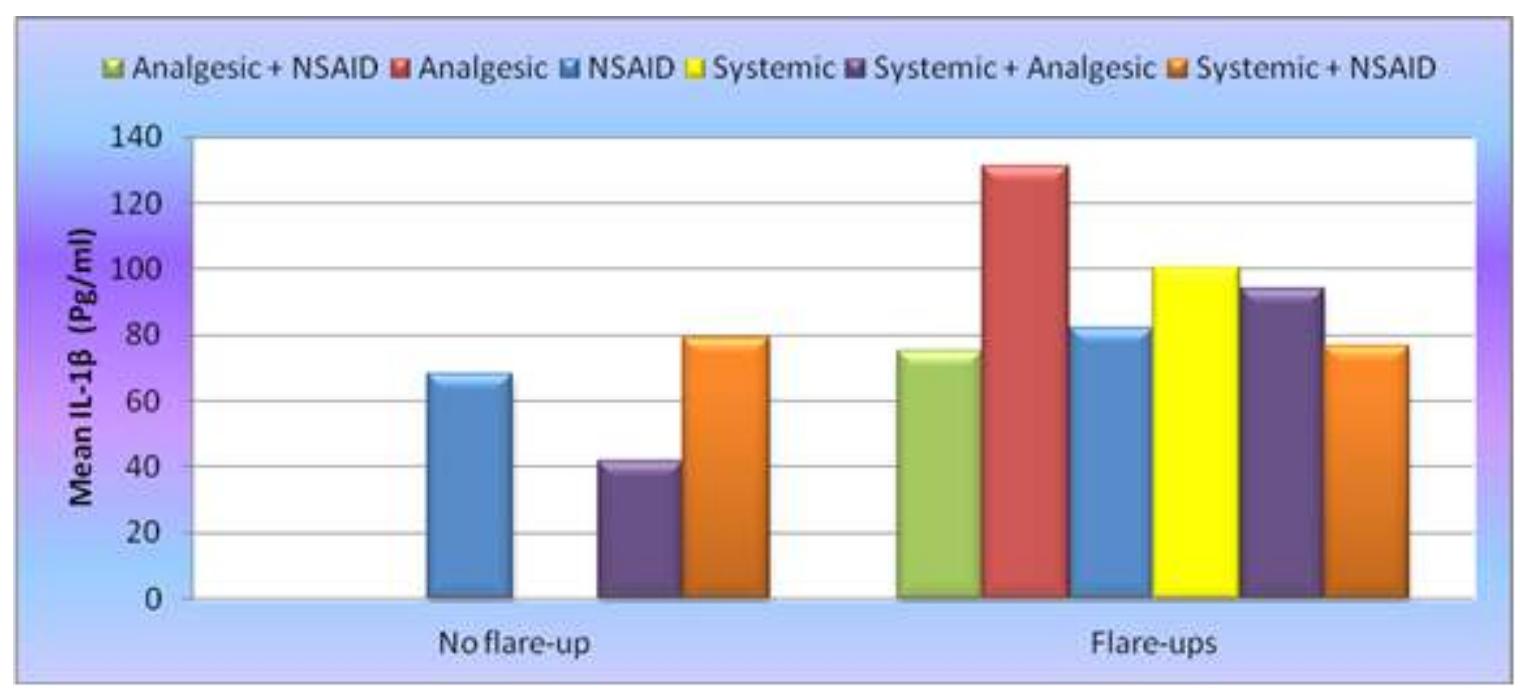

Figure (6): mean IL-1 $\beta$ levels with different medications

Table (7): correlation between MMP13 levels and different variables in patients with flare-ups

\begin{tabular}{c|cc}
\hline Variables & $\begin{array}{c}\text { Correlation } \\
\text { coefficient }\end{array}$ & P-value \\
\hline MMP13 and duration & 0.657 & $<0.001^{*}$ \\
\hline MMP13 and KL & 0.668 & $<0.001^{*}$ \\
\hline MMP13 and VAS & 0.572 & $<0.001^{*}$ \\
\hline MMP13 and Stiffness score & 0.621 & $<0.001^{*}$ \\
\hline MMP13 and Pain score & 0.571 & $<0.001^{*}$ \\
\hline MMP13 and Functional score & 0.554 & $<0.001^{*}$ \\
\hline MMP13 and Total WOMAC & 0.626 & $<0.001^{*}$ \\
\hline MMP13 and Lequen & 0.326 & $0.021^{*}$ \\
\hline MMP13 and KOFUS & 0.587 & $<0.001^{*}$ \\
\hline
\end{tabular}




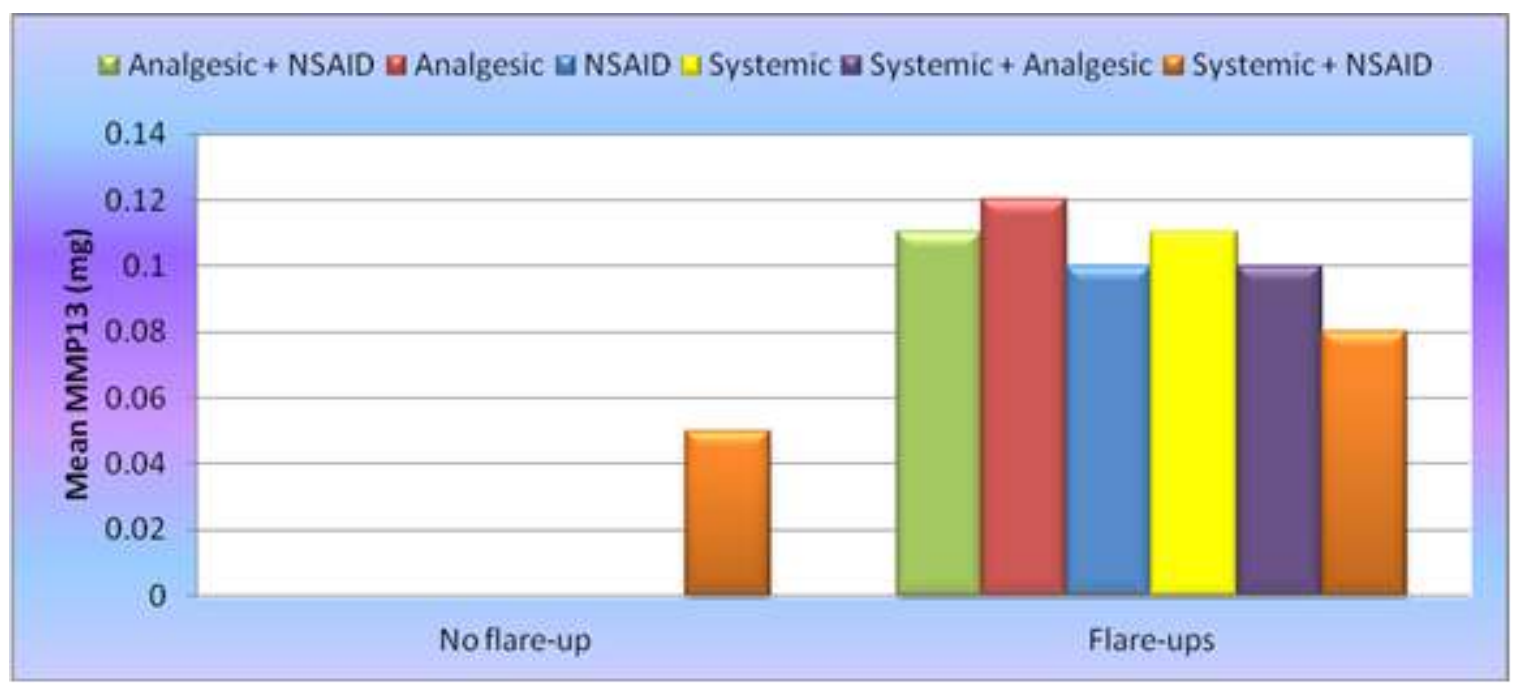

Figure (8): mean MMP13 levels with different medications 


\section{SUMMARY \&CONCLUSION}

The conclusion of our work was that there is a potential role for IL1 beta and MMP 13 biomarkers in assessing the development in osteoarthritis.

IL $1 \mathrm{~b}$ and MMP 13 were founded to be correlated positively in patients with knee OA this correlation sounded right as the expression of MMP 13 depends on the level of IL1 $b$.

Another important point in treatment is that although all medications groups failed to lower the level of IL $1 \mathrm{~b}$ and MMP 13,yet there was a numerical difference in favor of Diacerine and NSAID .

What is really important to be concluded from the study is that patients on both diacerine and NSAID had the lowerest rate of flare ups

It is recommended that the early measurement of biomarkers may detect cases to progress and thus stronger treatment may be given for these groups

\section{$\underline{\text { Recommendations }}$}

For all the previous reasons, we recommend:

*Undertaking further studies on a large scale with a large number of patients to confirm our promising results.

* For further understanding of the whole issue, serum and synovial fluid should be drawn from patients at the same time.

*Measuring these biomarkers at the risky patient groups and at the early phase of the disease to assess their role in the progression and destruction. 


\section{REFERENCES}

1 .Bijlsma JW, Berenbaum F, Lafeber FP;(2011): Osteoarthritis: an update with relevance for clinical practice.;377:2115-26.

2. Committee for Medicinal Products for Human Use. Guideline on clinical investigation of medicinal products used in the treatment of osteoarthritis. 2010.

3. Food and Drug Administration. Guidance for industry. Clinical development programs for drugs, devices, and biological products intended for the treatment of osteoarthritis. 2011.

4. Hunter DJ, Guermazi A;(2012): Imaging techniques in osteoarthritis. PM\&R;4:S68-74.

5. Atkinson AJ, Colburn WA, DeGruttola VG, et al;(2001):

Biomarkers Definitions Working Group. Biomarkers and surrogate endpoints: preferred definitions and conceptual framework. Clin Pharmacol Ther ;69:89-95. 